\title{
Penerapan Pathfinding Menggunakan Algoritma A* Pada Non Player Character (NPC) Di Game
}

\author{
Aditya Setiyawan ${ }^{1)}$, Paulus Harsadi ${ }^{2)}$, Sri Siswanti ${ }^{3)}$ \\ ${ }^{1,2,3)}$ Program Studi Teknik Informatika, STMIK Sinar Nusantara \\ ${ }^{1)}$ adityasetyawan38@gmail.com; ${ }^{2}$ paulusharsadi@ sinus.ac.id; ${ }^{3)}$ syswanty@ sinus.ac.id
}

\begin{abstract}
In this Game, we implement a character designer at the enemy by applying the algorithm $A *$ pathfinding Algorithm. Furthermore, $A *$ is as the algorithm for searching solutions with the use of additional information (heuristics) in which it is an optimal solution. The purpose of developing this Adventure Game is A* Algorithm implementation for Pathfinding using Unity 3D. Pathfinding is the fastest path of searching process from point of origin to point of destination by avoiding the various barriers along the path traveled without crashing the existing barrier along the way. Its design and development applies Unity 3D. The test result of algorithm in the Game shows that the total of passed node result is 50 nodes. It is similar with the previous manual count result. Furthermore, the Game route shows that its passed path is similar with manual count.

keywords : Game, pathfinding, Algoritma A*, non palyer character
\end{abstract}

\section{PENDAHULUAN}

Artificial Intelligence (AI) di game diharapkan mampu membuat karakter baik player maupun NPC (Non Player Character) memiliki perilaku manusia yang sesungguhnya baik bergerak maupun berfikir (Millington \& Funge, 2009). Pathfinding merupakan salah satu masalah di AI yang paling banyak digunakan terutama di game advanture seperti yang akan dibuat. Pathfinding merupakan salah satu teknik dalam game yang paling banyak diteliti karena pathfinding merupakan teknik utama atau dasar dalam pembuatan game (Adi Botea, et al., 2013).

Pathfinding sendiri dalam game diterapkan dalam bentuk variasi map yang berbeda dan pendekatan solusi yang berbeda-beda seperti yang pernah di paparkan oleh Ross Graham dalam makalahnya yang berjudul "pathfinding in Computer Game s" (Graham, McCabe, \& Sheridan, 2003).

Penerapan pathfinding meliputi analisa sebuah peta untuk menemukan nilai terbaik dalam perjalanan dari satu titik ke titik yang lain. Lintasan terbaik disini dapat diartikan tidak hanya sekedar lintasan terpendek, tetapi bisa diartikan nilai lintasan paling sedikit, atau lintasan yang aman (Yap, 2002). Tetapi, penerapan pathfinding dalam pembuatan game ini lebih focus digunakan untuk pencarian rute terpendek.

Penelitian pathfinding dalam game sudah cukup banyak dilakukan (Adi Botea, Bruno Bouzy, Michael Buro, Christian Bauckhage, 2013). Algoritma A*, atau A* pathfinding dan variasi perkembangan dari $A^{*}$ pathfinding sudah umum digunakan dalam AI Game dan merupakan metode yang paling banyak digunakan di game (Cowling et al., 2014)(Cui \& Shi, 2011). Algoritma ini juga dapat digunakan dalam berbagai bentuk grid sebagai bentuk map pada game dan dapat diterapkan dalam berbagai bentuk map dalam strategy game $s$ (Barnouti, Al-Dabbagh, \& Sahib Naser, 2016).

Algoritma $A^{*}$ sendiri pertama kali dikembangkan oleh P. Hart, N. Nilson dan B. Raphael pada tahun 1968 (Hart, Nilson, \& Raphael, 1968).

Pada game yang dibuat akan terdapat tokoh enemy yang akan menjadi Non Player Character (NPC) dengan menggunakan area hutan yang luas. Dimana pada nantinya NPC 
dirancang agar dapat mencari target utama / pemain dengan rute terpendek dan dapat menghindari penghalang yang ada di area game .

\section{TINJAUAN PUSTAKA}

\subsection{Algoritma $A^{*}$}

Algoritma $A^{*}$ menyelesaikan masalah yang menggunakan graph untuk perluasan ruang statusnya. Dengan kata lain digunakan untuk menyelesaikan permasalahan yang bisa direpresentasikan dengan graph. Algoritma $A^{*}$ adalah sebuah algoritma yang telah dikembangkan.

Dengan menerapkan fungsi heuristik, algoritma ini membuang langkah-langkah yang tidak perlu dengan pertimbangan bahwa langkah-langkah yang dibuang sudah pasti merupakan langkah yang tidak akan mencapai solusi yang diinginkan.

Didalam algoritma $A^{*}$ menggunakan dua senarai yaitu OPEN dan CLOSED. Pada algoritma $\mathrm{A}^{*}$ memiliki tiga kondisi dimana NPC berada di keadaan OPEN , berada dikeadaan CLOSED, dan tidak berada dikeduanya. Jika NPC dalam keadaan OPEN maka akan dilakukan pengecekan apakah perlu pengubahan parent atau tidak tergantung pada nilai g melalui parent lama maupun parent baru.

Jika NPC tidak berada dikeadaan OPEN maupun CLOSED, maka NPC tersebut akan dimasukan di dalam keadaan $O P E N$. Kemudian hitung biaya NPC tersebut dengan rumus $f$ $=g+h$. Algoritma $A *$ ini akan memberikan solusi terbaik yang optimal didalam arena.

$$
f(n)=g(n)+h(n)
$$

Keterangan :

$$
\begin{aligned}
f(n)= & \text { solusi biaya estimasi termurah } \\
& \text { verteks } \mathrm{n} \text { untuk mencapai tujuan. } \\
g(n)= & \text { biaya path / perjalanan. } \\
h(n)= & \text { biaya estimasi dari verteks } n \text { ke } \\
& \text { tujuan. }
\end{aligned}
$$

Suatu fungsi heuristik dapat dikatakan baik, apabila dapat memberikan biaya perkiraan yang mendekati biaya sebenarnya. Semakin mendekati biaya sebenarnya, fungsi heuristik tersebut semakin baik. Dalam masalah pencarian rute terpendek dengan graph, fungsi heuristik yang dapat digunakan adalah Manhattan Distance.

\subsection{Manhattan Distance}

Manhattan Distance adalah salah satu fungsi heuristik yang paling sering digunakan dalam menghitung jarak terdekat dari dua titik. Fungsi ini hanya menghitung selisih koordinat posisi titik awal dan titik akhirnya saja. Awalnya model ini digunakan di kota Manhattan, Amerika, karena di kota ini jarak dari dua lokasi dihitung dari blok- blok jalan yang harus dilalui saja, sehingga tidak bisa dilewati secara diagonal (Niedermeier \& Sanders, 1996). Fungsi heuristik ini dapat dihitung berdasarkan selisih jarak koordinat yang diambil dari dua buah titik, yang dapat diformulasikan menggunakan rumus (2).

$$
h(n)=a b c(n \cdot x-\text { tujuan. } x)+a b s(n . z-\text { tujuan.z })
$$

Keterangan :

$$
\begin{array}{ll}
n . x & : \text { Koordinat } \mathrm{x} \text { titik start } \\
n . z & : \text { Koordinat } \mathrm{z} \text { titik start } \\
\text { tujuan. } x & : \text { Koordinat } \mathrm{x} \text { titik tujuan } \\
\text { tujuan. } z & : \text { Koordinat } \mathrm{z} \text { titik tujuan }
\end{array}
$$


Fungsi dari $a b s$ diatas untuk mengubah nilai negatif menjadi nilai positif. ini terjadi apabila titik awal berada lebih jauh dari titik akhir (reverse), sehingga pengurangan $\mathrm{x} 2-\mathrm{x} 1$ mempunyai hasil yang negatif.

Game yang dibuat menggunakan game engine yaitu Unity 3D. Unity 3D adalah sebuah game engine yang berbasis cross-platform. Unity dapat digunakan untuk membuat sebuah game yang bisa digunakan pada perangkat komputer, ponsel pintar android, iPhone, PS3, dan bahkan X-BOX. Bahasa pemrograman yang dapat diterima Unity adalah JAVA SCRIPT, CS SCRIPT (C\#) \& BOO SCRIPT. Unity $3 D$ adalah salah satu software yang bagus untuk mengembangkan game $3 D$ dan selain itu juga merupakan software atau aplikasi yang interaktif dan atau dapat juga digunakan untuk membuat animasi 3 dimensi (Blackman, 2013).

\section{METODE PENELITIAN}

\subsection{Flowchart Permainan}

Game yang akan dibangun masuk dalam kategori game adventure yaitu berbasis pencarian atau pathfinding. Advanture game sendiri merupakan game yang membuat player berjalan dalam map menyelesaiakan masalah berdasarkan story line yang dibuat (Fairclough, et al., 2001). Flowchart desain level dalam game ini adalah seperti pada Gambar 1.

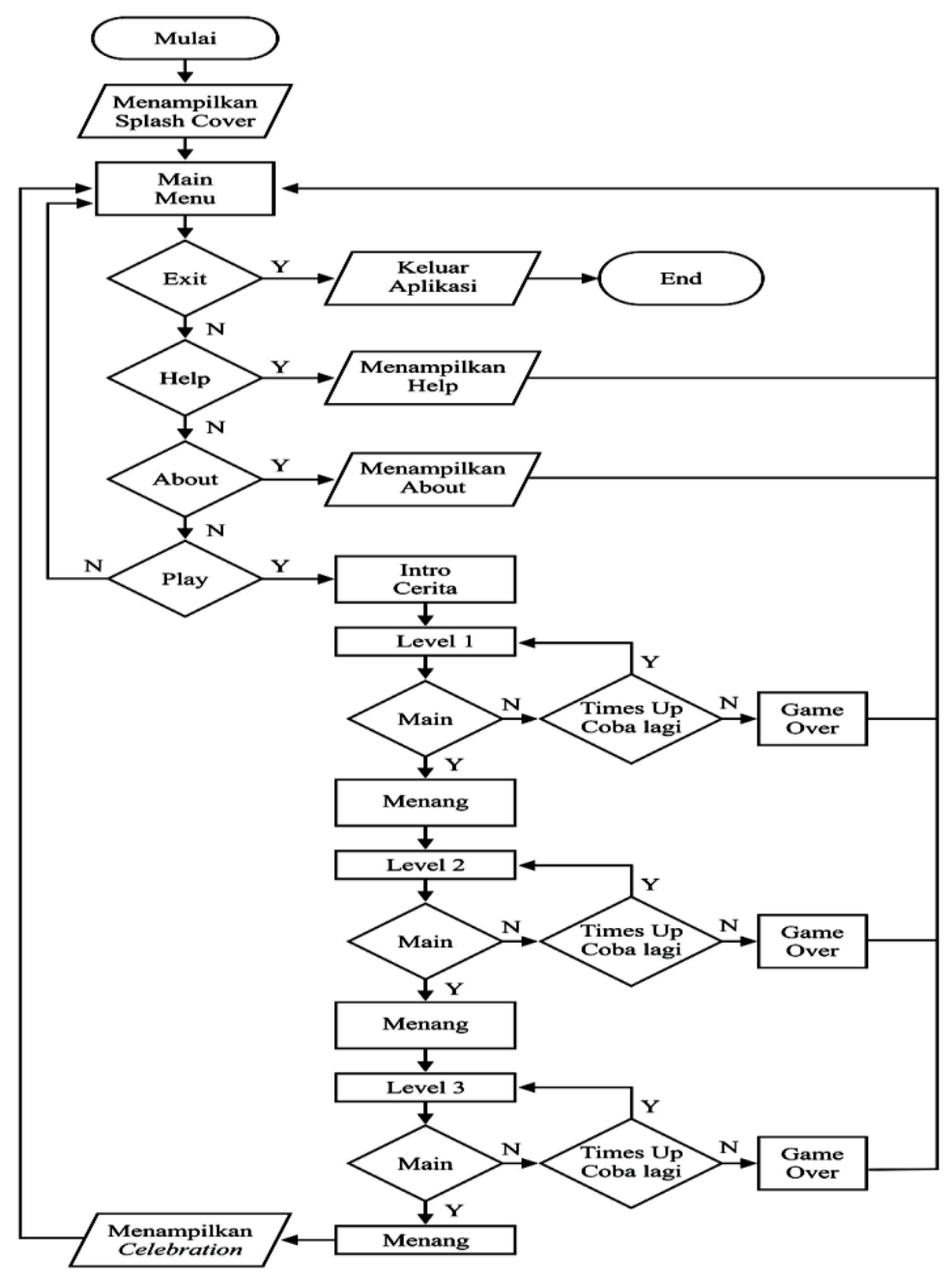

Gambar 1. Flowchart Game 


\subsection{Flowchart Algoritma A*}

Flowchart Algoritma A* dalam game ini adalah seperti pada Gambar 2

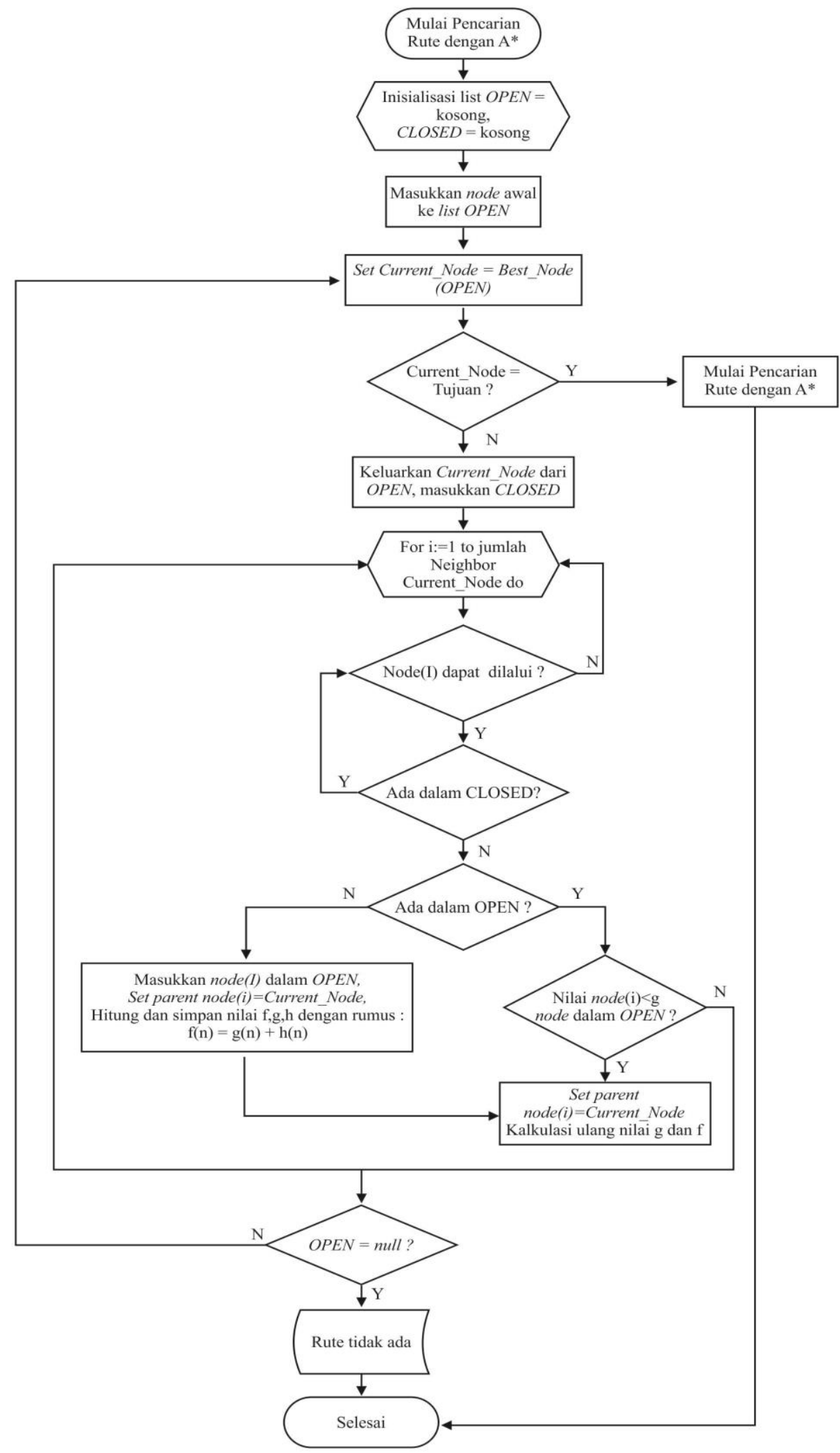

Gambar 2. Flowchart Algoritma A* 
Algoritma $\mathrm{A}^{*}$ akan diterapkan dalam proses pencarian atau pathfinding dalam game yang dibuat.

\section{HASIL DAN PEMBAHASAN}

\subsection{Deskripsi Karakter}

Terdapat beberapa tokoh karakter yang dibangun pada game ini, yaitu :

- Joko Kendhil (Karakter Player)

Karakter utama berperan sebagai Joko Kendhil, karakter ini yang memerankan sebagai first person dalam pencarian misi mendapatkan gong lokananta. Dengan menggunakan first person atau orang pertama mengacu pada perspektif grafis yang diberikan dari sudut pandang karakter pemain.

- NPC (Non Player Character)

Terdapat dua peranan sebagai NPC yakni yang pertama sebagai pesaing Joko Kendhil (Divisualkan sebagai sesama manusia) yang apabila mengenai objek NPC (manusia) tersebut tidak akan game over, dan yang kedua sebagai enemy (Divisualkan sebagai wujud hewan / burung) yang dimana kalau tertangkap NPC (burung) tersebut maka akan game over.

\subsection{Pembuatan Arena}

Arena dibuat dengan menggunakan arena sesungguhnya pada game, seperti Gambar 3.

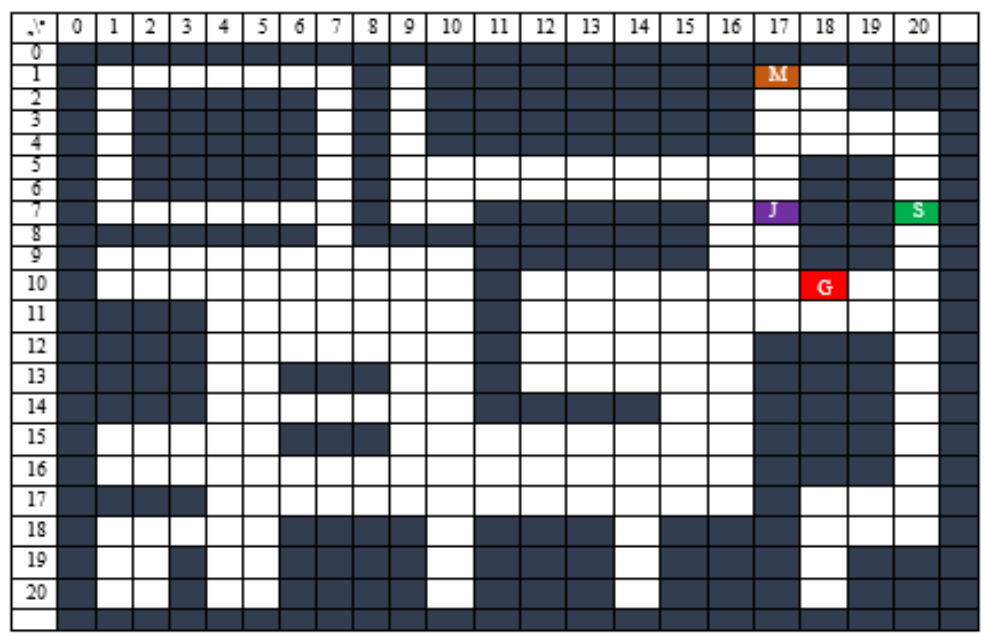

Gambar 3. Arena Game

Pada Gambar 3 adalah papan grid yang akan dirancang sebagai arena game yang telah dibuat menggunakan grid arena yang sebenarnya dengan menggunakan skala 1: 10 pada penerapannya.Warna hijau pada papan grid merupakan starting point Pesaing Joko Kendhil / NPC sebelum bergerak. Warna merah pada papan grid merupakan end point / Gong Lokananta yang akan dituju oleh Pesaing Joko Kendhil. Warna Ungu adalah sebagai starting point Joko Kendhil, Warna Orange adalah sebagai musuh / NPC yang mengejar Joko Kendhil, Warna biru dongker pada grid merupakan pepohonan yang tidak dapat dilewati dan warna putih adalah grid yang bisa dilewati. Nilai heuristik dihitung menggunakan fungsi manhattan1 yang nantinya akan digunakan dalam perhitungan A* pada Pesaing dan Musuh Joko Kendhil.

Tabel 1 merupakan nilai heuristik dihitung menggunakan fungsi manhattan1 yang nantinya akan digunakan dalam perhitungan A* pada Pesaing dan Musuh Joko Kendhil. 
Tabel 1. Nilai Heuristik (Pesaing Joko Kendhil)

\begin{tabular}{|c|c|c|c|c|c|}
\hline Start_X & Start_Z & Goal_X & goal_Z & $\begin{array}{c}\text { h(n)=abs(Start_X- } \\
\text { Goal_X)+abs(Start_Z- } \\
\text { Goal_Z) }\end{array}$ & Initial Node \\
\hline 1 & 1 & 10 & 18 & 26 & \\
\hline 1 & 2 & 10 & 18 & 25 & \\
\hline 1 & 3 & 10 & 18 & 24 & \\
\hline 1 & 4 & 10 & 18 & 23 & \\
\hline 1 & 5 & 10 & 18 & 22 & \\
\hline 1 & 6 & 10 & 18 & 21 & \\
\hline 1 & 7 & 10 & 18 & 20 & \\
\hline 1 & 9 & 10 & 18 & 18 & \\
\hline 1 & 17 & 10 & 18 & 10 & \\
\hline 1 & 18 & 10 & 18 & 9 & \\
\hline 2 & 1 & 10 & 18 & 25 & \\
\hline 2 & 7 & 10 & 18 & 19 & \\
\hline 2 & 9 & 10 & 18 & 17 & \\
\hline 2 & 17 & 10 & 18 & 9 & \\
\hline 2 & 18 & 10 & 18 & 8 & \\
\hline 3 & 1 & 10 & 18 & 24 & \\
\hline 3 & 7 & 10 & 18 & 18 & \\
\hline 3 & 9 & 10 & 18 & 16 & \\
\hline 3 & 17 & 10 & 18 & 8 & \\
\hline 3 & 18 & 10 & 18 & 7 & \\
\hline 3 & 19 & 10 & 18 & 8 & \\
\hline 3 & 20 & 10 & 18 & 9 & \\
\hline 4 & 1 & 10 & 18 & 23 & \\
\hline 4 & 7 & 10 & 18 & 17 & \\
\hline 7 & 9 & 10 & 18 & 12 & \\
\hline 7 & 10 & 10 & 18 & 11 & \\
\hline 7 & 16 & 10 & 18 & 5 & \\
\hline 7 & 17 & 10 & 18 & 4 & \\
\hline 7 & 20 & 10 & 18 & 5 & START \\
\hline 8 & 7 & 10 & 18 & 13 & \\
\hline 8 & 16 & 10 & 18 & 4 & \\
\hline 10 & 4 & 10 & 18 & 14 & \\
\hline 10 & 5 & 10 & 18 & 13 & \\
\hline 10 & 6 & 10 & 18 & 12 & \\
\hline 10 & 7 & 10 & 18 & 11 & \\
\hline 10 & 8 & 10 & 18 & 10 & \\
\hline 10 & 9 & 10 & 18 & 9 & \\
\hline 10 & 10 & 10 & 18 & 8 & \\
\hline 10 & 12 & 10 & 18 & 6 & \\
\hline 10 & 13 & 10 & 18 & 5 & \\
\hline 10 & 14 & 10 & 18 & 4 & \\
\hline 10 & 15 & 10 & 18 & 3 & \\
\hline 10 & 16 & 10 & 18 & 2 & \\
\hline 10 & 17 & 10 & 18 & 1 & \\
\hline 10 & 18 & 10 & 18 & 0 & GOAL \\
\hline 10 & 19 & 10 & 18 & 1 & \\
\hline 10 & 20 & 10 & 18 & 2 & \\
\hline 11 & 4 & 10 & 18 & 15 & \\
\hline 11 & 5 & 10 & 18 & 14 & \\
\hline 11 & 6 & 10 & 18 & 13 & \\
\hline 11 & 7 & 10 & 18 & 12 & \\
\hline 11 & 8 & 10 & 18 & 11 & \\
\hline 11 & 9 & 10 & 18 & 10 & \\
\hline 11 & 10 & 10 & 18 & 9 & \\
\hline 11 & 12 & 10 & 18 & 7 & \\
\hline 11 & 13 & 10 & 18 & 6 & \\
\hline
\end{tabular}


Kemudian dengan Gambar 4 pada biaya perkiraan dan juga nilai cost untuk bergerak atau berpindah grid dengan perkiraan biaya sebesar 10, maka akan dilakukan penghitungan sesuai fungsi $f(n)=g(n)+h(n)$ pada node yang terhubung langsung dengan node awal saat ini. Berikut langkah pencarian pada algoritma A* Pathfinding:

- Langkah 1

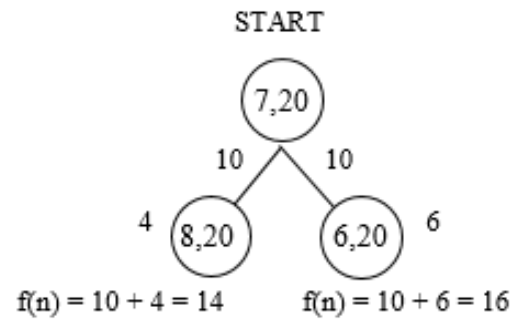

Gambar 4. Perhitungan langkah 1

Langkah 1 seperti pada Gambar 4, didapat nilai pada simpul pertama yaitu $\mathrm{f}(\mathrm{n})=10$ $+4=14$ dan $\mathrm{f}(\mathrm{n})=10+6=16$, maka akan di cabangkan pada simpul kedua terlebih dahulu. Simpan node $[7,20]$ didalam CLOSED list, sedangkan node $[8,20]$ dan $[6,20]$ didalam OPEN list. Langkah pergerakan papan grid seperti pada Gambar 5.

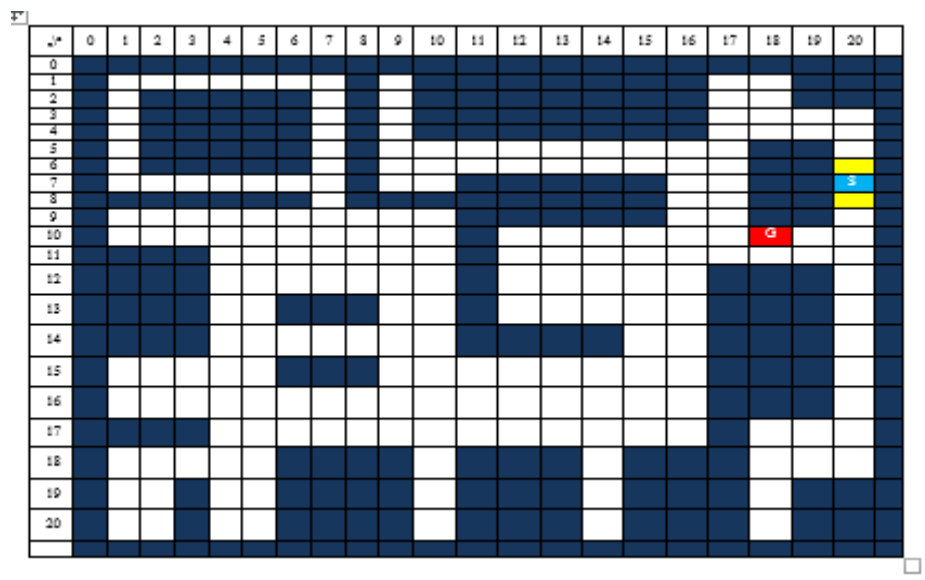

Gambar 5. Langkah pergerakan papan grid

Dari perhitungan awal diatas, maka pergerakan didalam papan grid akan ditandai dengan kotak warna kuning sebagai OPEN List dan kotak warna biru nantinya merupakan CLOSED List.

- Langkah 2

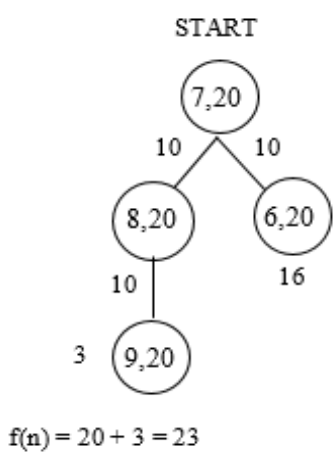

Gambar 6. Perhitungan langkah 2 
Pada Langkah 2 seperti pada Gambar 6, Simpan node $[7,20][8,20]$ kedalam CLOSED list serta node [9.20] dan [6,20] ke dalam OPEN list. Maka pergerakan dalam papan grid seperti Gambar 7.

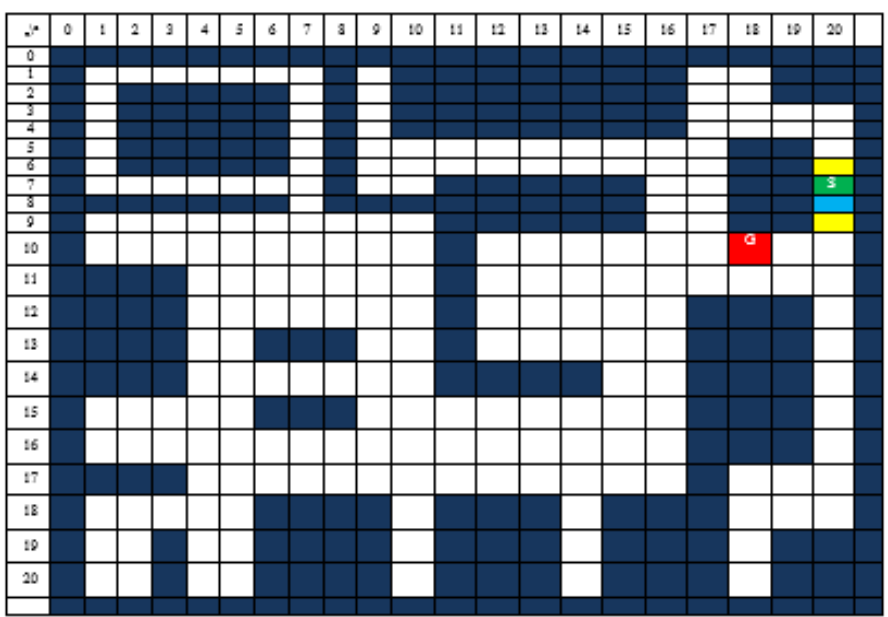

Gambar 7. Langkah 2 pergerakan papan grid

Ulangi langkah seperti sebelumnya dengan mencari nilai f yang paling rendah kemudian hitung menggunakan rumus $\mathrm{A}^{*}$.

Kemudian ulangi langkah tadi hingga menemukan tujuan dengan nilai simpul paling rendah (best node).

- Langkah 12

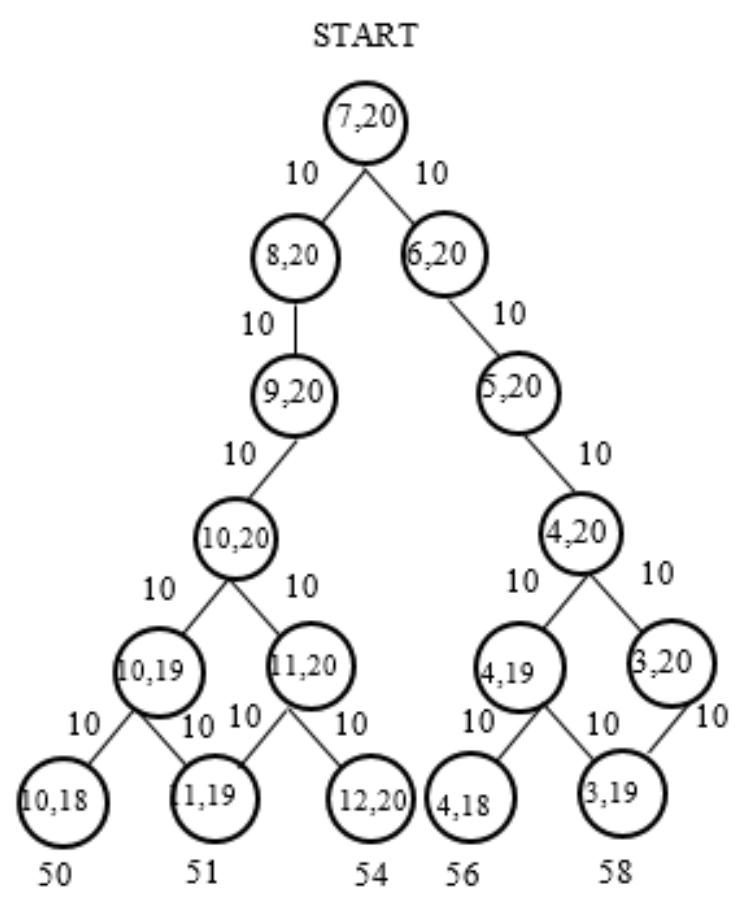

Gambar 8. Perhitungan Langkah 12

Pada langkah ke 12 seperti pada Gambar 8 didapatkan hasil pencarian Algoritma A* pathfiding dengan hasil jalur terpendeknya dimulai dari node $[7,20][8,20][9,20][10,20]$ 
$[10,19][10,18]$ dengan jumlah biaya 50 yang merupakan biaya paling kecil. Pergerakan terakhir pada papan Grid seperti pada Gambar 9.

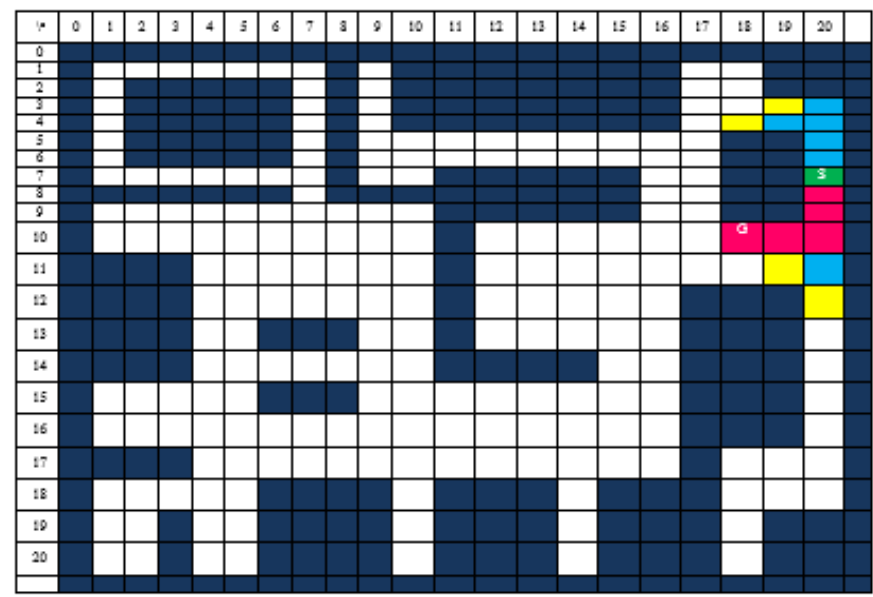

Gambar 9. Pergerakan terakhir pada papan grid

\subsection{Implementasi}

Pada tahap ini dilakukan pembuatan desain game. Berikut adalah implemetasi game pada bagian utama.

a. Pembangunan Terrain Hutan

Terrain merupakan bentuk map dari game secara keseluruhan disetiap levelnya. Peta game yang dibuat berbasis grid yang akan digunakan untuk pathfinding oleh Player maupun Non Player Character. Penegmbangan Terrain Hutan seperti pada Gambar 10.

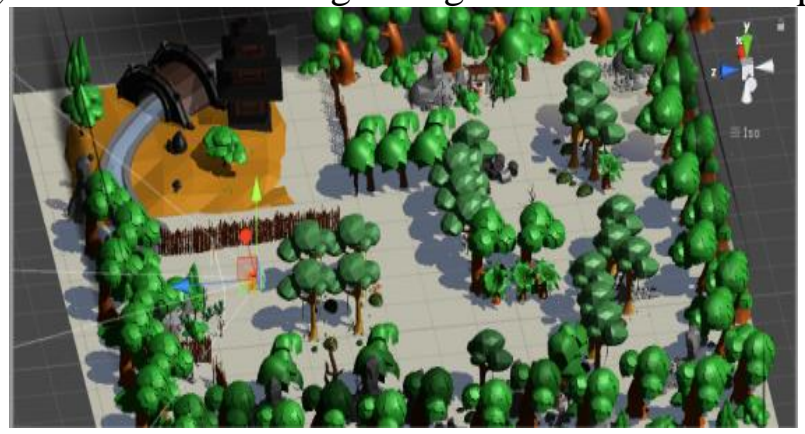

Gambar 10. Terrain Hutan

b. Tampilan Game

Gambar 11 merupakan bentuk tampilan game ketika Player melakukan eksplorasi pada peta.

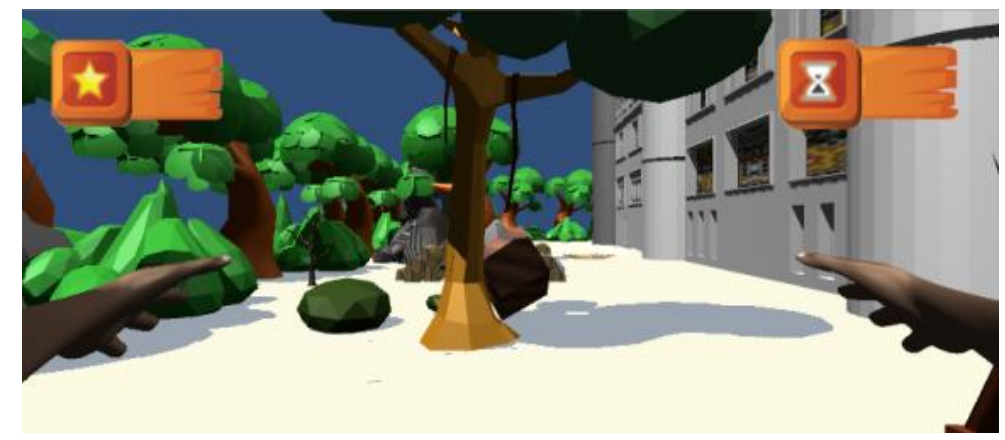

Gambar 11. Tampilan Game 


\subsection{Pengujian}

Pengujian validitas lebih dilakukan uji mengenai perhitungan algoritma itu sendiri yaitu algoritma $\mathrm{A}^{*}$. Hal yang diuji adalah perbandingan hasil perhitungan manual algoritma dengan perbandingan aplikasi yang berjalan. Pada perhitungan manual perbandingan hasilnya dapat dilihat pada Tabel 2 dan Gambar 12.

Tabel 2. Perhitungan Manual

\begin{tabular}{|c|c|c|c|}
\hline $\begin{array}{l}\text { Node } \\
\text { Start }\end{array}$ & $\begin{array}{c}\text { Node } \\
\text { Tujuan }\end{array}$ & Kemungkinan Rute Manual (Terdekat) & $\begin{array}{c}\text { Besar biaya } \\
\text { (satuan kotak) }\end{array}$ \\
\hline \multirow{4}{*}[7,20]{} & \multirow{4}{*}[10,18]{} & {$[8,20][9,20][10,20][10,19][10,18]$} & Panjang lintasan $=5$ \\
\hline & & $\begin{array}{l}{[8,20][9,20][10,20][11,20][11,19][11,18]} \\
{[10,18]}\end{array}$ & Panjang lintasan $=7$ \\
\hline & & $\begin{array}{l}{[6,20][5,20][4,20][4,19][4,18][4,17][5,17]} \\
{[6,17][7,17][8,17][9,17][10,17][10,18]}\end{array}$ & Panjang lintasan $=13$ \\
\hline & & $\begin{array}{l}{[6,20][5,20][4,20][3,20][3,19][3,18][3,17]} \\
{[4,17][5,17][6,17][7,17][8,17][9,17][10,17]} \\
{[10,18]}\end{array}$ & Panjang lintasan $=15$ \\
\hline
\end{tabular}

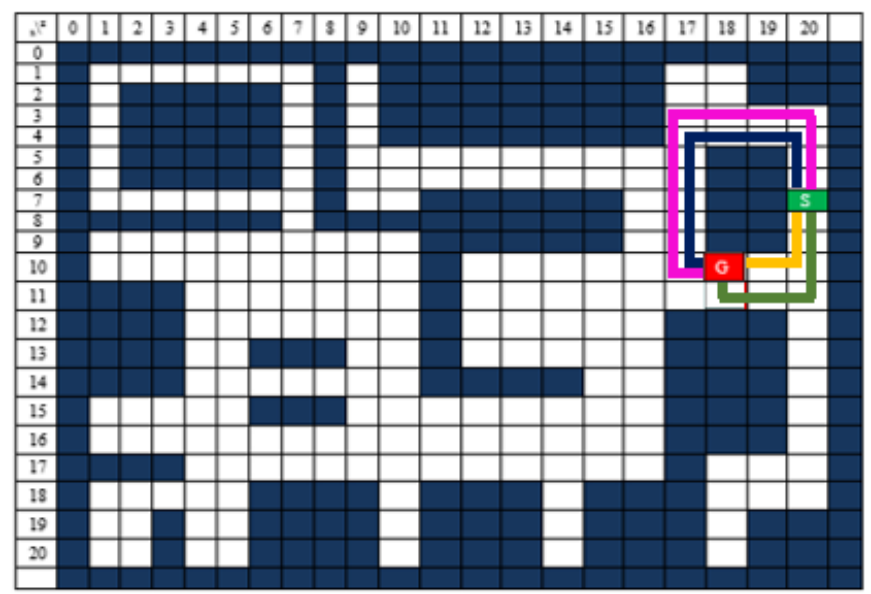

Gambar 12. pergerakan papan grid manual

Dari hasil perhitungan secara manual pada Tabel 2 yang telah dilakukan maka akan didapat 4 kemungkinan rute terdekat A menuju B dari arena sebenarnya.

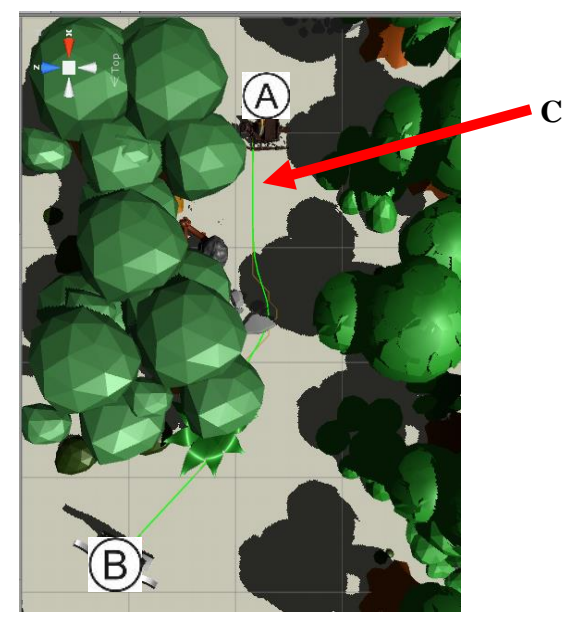

Gambar 13. Rute terbaik NPC pada Game 
Titik A merupakan titik awal pathfinding, dan titik B merupakan titik tujuan sedang C yang berwarna hijau merupakan node optimal hasil perhitungan algoritma $\mathrm{A}^{*}$ dalam game dan merupakan solusi tercepat jarak yang bisa ditempuh.

Solusi optimal pada console game pada Gambar 13 yaitu sebanyak 50 node, sesuai seperti perhitungan manual sebelumnya.

Tabel 3. Tabel Pengujian Program

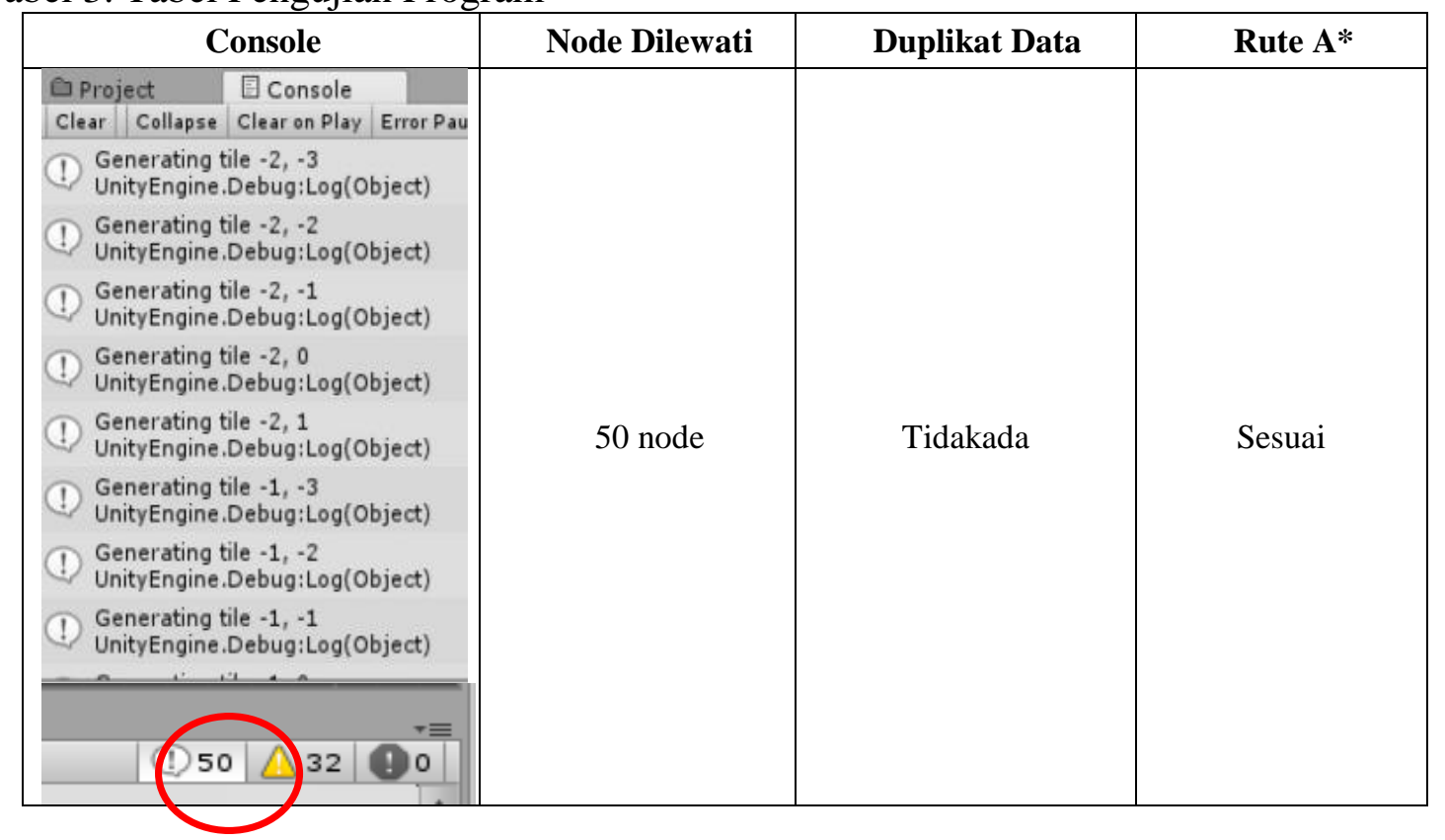

Serta akan didapat solusi optimal pada console game seperti diatas yaitu sebanyak 50 node, sesuai seperti perhitungan manual sebelumnya.

\section{KESIMPULAN DAN SARAN}

\subsection{Kesimpulan}

Algoritma A* berhasil diterapkan sebagai pembangkit perilaku pencarian pada NPC pada game yang dibuat. Hasil pengujian algoritma yang didapat adalah hasil node yang dilewati yakni sebanyak 50 node, hal tersebut sama dengan hasil perhitungan manual algoritma $\mathrm{A}^{*}$.

Rute player dalam melakukan eksplorasi dalam peta game menunjukkan rute jalur yang sama dengan perhitungan manual menggunakan algoritma $A^{*}$ dan merupakan rute tercepat yang bisa dilalui.

\subsection{Saran}

Penggunaan algoritma A* pada game yang dibuat masih berbasis grid. Implementasi kedepan diharapkan algoritma $\mathrm{A}^{*}$ bisa diimplementasikan pada area yang berbasis navigation mesh sehingga komputasi algoritma $A^{*}$ lebih cepat dalam menemukan titik tujuan. 


\section{DAFTAR PUSTAKA}

Adi Botea, Bruno Bouzy, Michael Buro, Christian Bauckhage, D. N. (2013). Pathfinding in Game s. https://doi.org/10.4230/DFU.Vol6.12191.21

Barnouti, N. H., Al-Dabbagh, S. S. M., \& Sahib Naser, M. A. (2016). Pathfinding in Strategy Game s and Maze Solving Using A* Search Algorithm. Journal of Computer and Communications, 04(11), 15-25. https://doi.org/10.4236/jcc.2016.411002

Blackman, S. (2013). Beginning 3D Game Development with Unity 4: Beginning 3D Game Development with Unity 4: https://doi.org/10.1007/978-1-4302-4900-9

Cowling, P., Buro, M., Bida, M., Botea, A., Bouzy, B., Butz, M., ... Sipper, M. (2014). Search in Real-Time Video Game s. Artificial and Computational Intelligence in Game s, 6, 1-19. https://doi.org/http://dx.doi.org/10.4230/DFU.Vol6.12191.1

Cui, X., \& Shi, H. (2011). A*-based Pathfinding in Modern Computer Game s. International Journal of Computer Science and Network Security, 11(1), 125-130. Retrieved from http://paper.ijcsns.org/07_book/201101/20110119.pdf

Fairclough, C., Fagan, M., Mac Namee, B., \& Cunningham, P. (2001). Research Directions for AI in Computer Game s. Irish Conference on Artificial Intelligence and Cognitive Science, 333-344. Retrieved from http://citeseerx.ist.psu.edu/viewdoc/download?doi=10.1.1.17.2579\&amp;rep=rep1\&a mp;type $=$ pdf

Graham, R., McCabe, H., \& Sheridan, S. (2003). Pathfinding in computer Game s. ITB Journal, 4(2), 1-26. https://doi.org/10.4230/DFU.Vol6.12191.21

Hart, P., Nilson, N., \& Raphael, B. (1968). A formal basis for the heuristic determination of minimum cost paths. IEEE Trans. Syst. Sci. Cybern. 4.

Millington, I., \& Funge, J. (2009). Artificial Intelligence for Game s, Second Edition. Representations. https://doi.org/10.1017/S0263574700004070

Niedermeier, R., \& Sanders, P. (1996). On the Manhattan-Distance Between Points on Space-Filling Mesh-Indexings. Univ. Fak. Fur Informatik, 1-10.

Yap, P. (2002). Grid-based path-finding. Advances in Artificial Intelligence, 44-55. 